\title{
Recombinant Human Erythropoietin (rHuEPO) Reduces Transfusion Requirements in Anaemia of Prematurity
}

\author{
B H N Yasmeen ${ }^{1}$, S Akhter ${ }^{2}$, F Akhter ${ }^{3}$, R Jahann ${ }^{4}$, M Hassan $^{5}$, M M Hoque $^{6}$
}

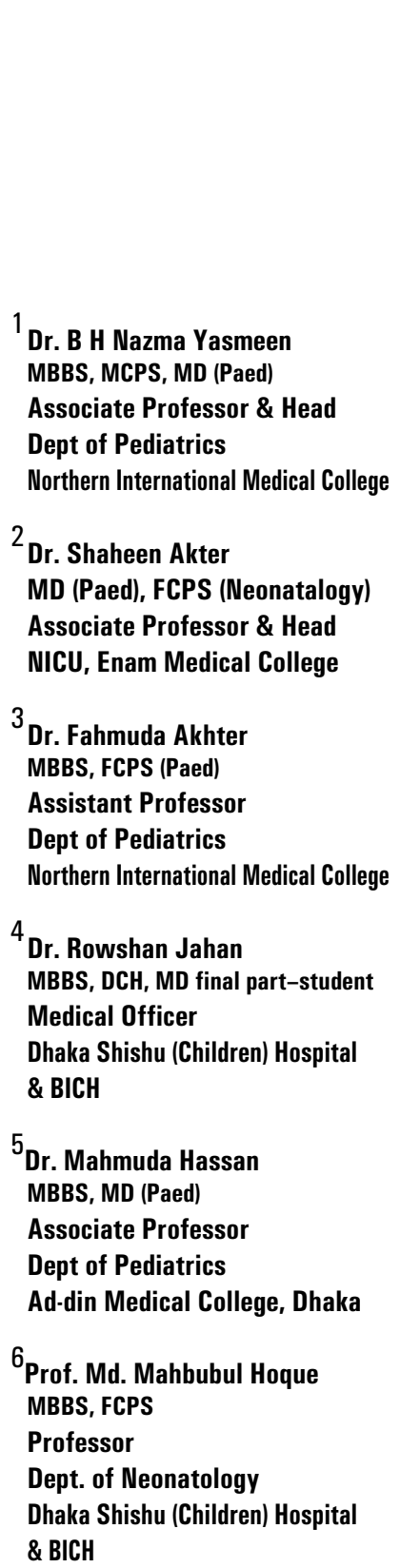

\section{Correspondence}

Dr. B H Nazma Yasmeen Associate Professor \& Head Dept of Pediatrics

Northern International Medical College email : drnazmayasmeen @ yahoo.com
Abstract

\section{Background}

During the last two decades with the application of advanced technological supports have improved the survival rate of preterm very low birth weight (PT VLBW) infants. At the same time anemia of prematurity (AOP) one of the most frequent complications of these patients also has been increased in the neonatal units. Packed red blood cell (PRBC) transfusions are the mainstay of treatment of AOP. The frequency of blood transfusion is directly related to the exposure of the tiny preterm infants to various risks of transfusion.

Objectives : To evaluate whether recombinant human erythropoietin (rHuEPO) therapy reduces the need of transfusions in AOP.

Methods : A randomized controlled trial study was carried out at Neonatal Unit and Intensive Care Unit (ICU) of Dhaka Shishu (children) Hospital, Dhaka, Bangladesh with 60 PTVLBW neonates. Among them 30 in group I (rHuEPO group) and 30 in group II (control) were assigned. Therapy with rHuEPO (200 IU / kg / dose) thrice weekly was initiated on day 7 of life to group I for 2 weeks. From day 14 or after that as soon as enteral feeding was initiated oral iron and folic acid were received by both groups. Hematological assessment (haemoglobin, haematocrit level and reticulocyte count) were done at 6 and 10 weeks of life.

Results : At the time of enrollment in the study PTLBW babies of both groups were almost similar in gestetional age, birth weight, hemoglobin, hematocrit values and reticulocyte count $(p>0.05)$. During the 10 weeks observation period, hematological values were increased and the number of blood transfusions as well as the number of infants who received any transfusion were reduced in rHuEPO group compared to control group $(p<0.01)$. No adverse effect of erythropoietin were found.

Conclusion : The combination of rHuEPO and Iron, folic acid therapy significantly reduces the number of blood transfusion as well as the percentage of infants who received any transfusion in AOP.

Key words : Prematurity, AOP, rHuEP

\section{Introduction}

After birth as the neonate transitions from a relatively hypoxic state in the uterus to a relatively hyperoxic state in the room air causes increased tissue oxygenation. Ultimately which leads to a decline in erythropoietin (EPO) concentration, for the term infant a physiologic and usually asymptomatic anaemia develops at the age of 8-12 weeks. But anaemia of prematurity (AOP) is an exaggerated and pathologic response of the preterm infant to this transition. The shortened half-life of fetal red blood cells ${ }^{1}$, an expansion of extra cellular volume given by rapid body growth $^{1}$, nutritional imbalances ${ }^{2}$ and more blood loss due to phlebotomy for laboratory testing ${ }^{3}$ all play important roles in accentuating the generation of anemia of prematurity.

The preterm babies may have PCV below $30 \%$ and $\mathrm{Hb}$ below $10 \mathrm{~g} / \mathrm{dl}^{4}$ at this condition. In a well term baby, the nadir of haemoglobin is as low as $9.4-11 \mathrm{~g} / \mathrm{dl}$ and occurs at 8-12 weeks of age, for a preterm infant, the nadir of haemoglobin occurs earlier (4-8 weeks of age) and is lower $(6.5-9 \mathrm{~g} / \mathrm{dl})^{5}$. AOP is a normocytic-normochromic and hypo-regenerative anaemia that is characterized by the existence of a low serum EPO level with a remarkably low haemoglobin concentration ${ }^{6}$.

Packed red blood cell (PRBC) transfusions is the mainstay of therapy for the infant with AOP. Transmission of Viral infection-CMV, HCV, HBV, HIV etc, volume overload alloimmunisation, immunosuppression, electrolyte $\&$ acid base status disruption etc. are the important risk of blood transfusion in pre-term infants. Everyday there is an increase in the number of potentially infectious agents transmissible by this route. An example of this are the prions whose repercussions are still unknown to the human species, although the medical world is already alerted to its potential risks. However, since it is the central theme of the recent publications of Nora Hunter et al. entitled "Transmission of prion diseases by blood transfusion"7 in which the possibility of transmission of spongiform encephalitis through this pathway arises. Moreover since recently has been describing the death of adult patients associated with the transmission of West Nile virus, also transmitted through blood transfusions ${ }^{8,9}$ According to an FDA report (between 1986 and 1991) 16\% of fatal transfusion would have been contaminated with bacterial agents. Among them are Pseudomonas, Yersinia and other bacteria like Staphylococcus epidermidis. ${ }^{10} \mathrm{~A}$ developing country has certainly the security of blood transfusion, in regard to transmission of infections is far below than those of the developed countries. A recent report showed that a large number of blood units were not subjected to any screening at Latin America. ${ }^{11}$ On the other hand there are reports that association of early transfusions in premature (during the first week of life) with the development of retinopathy of prematurity and Bronchopulmonary Dysplasia. ${ }^{12}$

In our situation Recombinant erythropoietin therapyoffers promise in ameliorating the anaemia of 
prematurity ${ }^{13}$. Although studies showed that rHuEPO decreases the frequency and volume of RBC transfusions in premature infants. ${ }^{14} \mathrm{~A}$ meta-analysis of the most scientifically rigorous studies on this topic indicates that administration of rHuEPO to VLBW infants reduces erythrocyte transfusion in a dose dependant manner. ${ }^{15}$

Reducing the number of transfusions, reducing the number of donor exposures and other hazards of transfusion is important for a PTVLBW infant and which can be accomplished by Recombinant human erythropoietin therapy.

Therefore this study was carried out to evaluate whether the rHuEPO therapy would (1) reduces the number of transfusions received (2) decreases the percentage of infants who received any transfusions.

\section{Methods}

From April 2007 - May 2008 Sixty VLBW infants were enrolled in a randomized controlled trial after their parents or guardian gave written consent. Infants were eligible for the study if they fulfilled all the following criteria: (1) gestational age at birth-less than 35 weeks (2) birth weight less than $1500 \mathrm{gm}$ (3) age-less than 7 days (4) clinically stable.

Neonates with (1) IUGR (2) anemia due to other causes (ABO or Rh incompatibility) (3) gross congenital anomalies (eg. Congenital Heart Diseases, Chromosomal anomalies etc) and (4) acutely ill patients (electrolyte-acid-base disturbances, acquired or congenital infections) were excluded.

The infants were randomly assigned to receive rHuEPO (group I, n=30) $200 \mathrm{U} / \mathrm{kg}$ subcutaneously three times per week for two weeks started on day 7 of life or no rHuEPO (group II, $n=30$ ), according to a schedule generated by a random-number table. Patients of both groups received oral Iron $6 \mathrm{mg} / \mathrm{kg} / \mathrm{day}$ and Folic acid $0.5 \mathrm{mg}$ every alternate day up to 12 weeks of life. Both Iron and Folic acid administration started from day 14 of life or as soon as enteral feeding was initiated after day 14 . Haematological Assessment i,e Haemoglobin concentration ( $\mathrm{Hb}$ ), Reticulocyte count, Platelet count (PIt) and Hematocrit (Hct) value was done for both groups on day 7 before administration of rHuEPO (for baseline investigation) and during the follow up at 6 weeks and 10 weeks of age at the hospital pathology department. Haematological assessment was also done at any time if clinical anaemia was found. During discharge from the hospital parents were advised to come for follow up at 6 weeks and 10 weeks of age. Hematological assessment were done during both visits.

Packed red blood cell (PRBC) transfusion was administered according to the transfusion protocol of the Neonatal Unit and Intensive Care Unit (ICU) of Dhaka Shishu (children) Hospital. Any patient with Haemoglobin level of $7 \mathrm{gm} / \mathrm{dl}$ were managed with packed cell transfusion (10 $\mathrm{ml} / \mathrm{Kg}$ body weight). This was applicable for both admitted or follow-up patients.

The study protocol was approved by the Ethical Review Committee of Dhaka Shishu (children) Hospital and Bangladesh Institute of Child Health, Dhaka.

Appropriate statistical analysis was done with SPSS version 12.0 (Statistical package of social service Inc, Chicago, USA). The results were presented in tables. For significance of difference unpaired Student' $t$ ' test and chi-square test were done. A probability ' $p$ ' value < 0.05 was considered as significant.

\section{Results}

Total 60 preterm very low birth weight neonates were enrolled in the study. Thirty patients in each group. Group I supplemented with rHuEPO, iron and folic acid and Group II supplemented with iron and folic acid. In group I, 4 infants died during hospital stay and 1 patient did not come in $1^{\text {st }}$ follow up and 1 in $2^{\text {nd }}$ follow up. In Group II, 5 infants died during hospital stay and 2 did not come in $2^{\text {nd }}$ follow up. Finally 24 infants in Group I and 23 infants in Group II completed the follow up until 10 weeks of age (Table-I). These 13 dropped out infants were excluded from the analysis. No adverse effect of erythropoietin were found in this study.

Table 1 : Distribution of population of the study

\begin{tabular}{|l|c|c|c|}
\hline & \multirow{2}{*}{ number of patients } & $\begin{array}{c}\text { Group I } \\
\text { (rHuEPO) }\end{array}$ & $\begin{array}{c}\text { Group II } \\
\text { (Control) }\end{array}$ \\
\cline { 3 - 4 } & & number & number \\
\hline Total enrollment & 60 & 30 & 30 \\
At 1st follow up & 50 & 25 & 25 \\
At 2nd follow up & 47 & 24 & 23 \\
\hline
\end{tabular}

Neonates of both groups were matched and similar in age, sex, gestational age, birth weight, length and OFC during the admission. This study showed slight male preponderance. (in group I number of male was 18 i.e. $60 \%$ and in group II male was 19 i.e. $63.3 \%$ ). Baseline clinical and hematological values ( $\mathrm{Hb}$, Hct, Reticulocyte count) were estimated and no significant differences $(p>0.05)$ were found between the two groups (Table- II-III).

Table II : Distribution of patients by sex

\begin{tabular}{|c|c|c|c|c|c|c|}
\hline \multirow{2}{*}{ Sex } & \multicolumn{2}{|c|}{$\begin{array}{c}\text { Group I } \\
(\mathrm{n}=30)\end{array}$} & \multicolumn{2}{c|}{$\begin{array}{c}\text { Group II } \\
(\mathrm{n}=30)\end{array}$} & Chi Value & P Value \\
\cline { 2 - 5 } & $\mathrm{n}$ & $\%$ & $\mathrm{n}$ & $\%$ & & \\
\hline Male & 18 & 60.0 & 19 & 63.3 & & \\
\hline Female & 12 & 40.0 & 11 & 36.7 & \multirow{2}{*}{0.07} & 0.790 \\
\hline
\end{tabular}

Table III : Base line clinical characteristics

\begin{tabular}{|l|cc|c|c|}
\hline & $\begin{array}{c}\text { Group I } \\
(\mathrm{n}=30)\end{array}$ & $\begin{array}{c}\text { Group II } \\
(\mathrm{n}=30)\end{array}$ & t value & P value \\
\hline $\begin{array}{l}\text { at the time of } \\
\text { admission }\end{array}$ & Mean \pm SD & Mean \pm SD & & \\
\hline $\begin{array}{l}\text { Gestational age } \\
\text { Birth weight }\end{array}$ & $30.4 \pm 0.9$ & $30.2 \pm 1.2$ & 0.858 & 0.395 \\
Length & $1348.3 \pm 50.1$ & $1365.1 \pm 68.4$ & 1.087 & 0.282 \\
OFC & $40.1 \pm 1.2$ & $39.8 \pm 1.2$ & 0.976 & 0.333 \\
\hline Basline Hematologic & $29.4 \pm 0.9$ & $29.0 \pm 0.8$ & 1.910 & 0.061 \\
values at day 7 of life & & & \\
\hline Hb gm/dl & $14.9 \pm 1.1$ & $15.4 \pm 1.3$ & 1.665 & 0.102 \\
Hematocrit \% & $45.9 \pm 3.3$ & $47.3 \pm 3.2$ & 1.663 & 0.102 \\
Reticulocyte count \% & $1.8 \pm 0.8$ & $2.2 \pm 0.7$ & 1.852 & 0.069 \\
MCV fl & $106.0 \pm 3.5$ & $107.8 \pm 4.0$ & 1.888 & 0.064 \\
Platelet K/ $\mu \mathrm{L}$ & $214.2 \pm 49.5$ & $212.0 \pm 45.4$ & 0.176 & 0.861 \\
\hline
\end{tabular}

During hospital stay in the first 3 weeks of their life, total number of neonates (7 vs 8$)$, number of transfusions ( $2.1 \pm 0.6$ vs1.9 \pm 0.6$)$ and age at which blood transfusions required (11.4 \pm 2.8 vs $12.2 \pm 1.8$ days) were almost similar in both groups (Table-IV-V). 
Table IV : Blood transfusion (BT) requirements during hospital stay

\begin{tabular}{|c|c|c|c|c|c|c|}
\hline \multirow[t]{2}{*}{ Sex } & \multicolumn{2}{|c|}{$\begin{array}{l}\text { Group I } \\
(n=24)\end{array}$} & \multicolumn{2}{|l|}{$\begin{array}{c}\text { Group II } \\
(n=23)\end{array}$} & \multirow[t]{2}{*}{ Chi Value } & \multirow[t]{2}{*}{ P Value } \\
\hline & $\mathrm{n}$ & $\%$ & $\mathrm{n}$ & $\%$ & & \\
\hline No. of neonate required BT & 7 & 29.2 & 8 & 34.8 & \multirow{3}{*}{0.17} & \multirow{3}{*}{0.679} \\
\hline & & & & & & \\
\hline No. of. neonate with out BT & 17 & 70.8 & 15 & 65.2 & & \\
\hline
\end{tabular}

Table V : Blood transfusion status during hospital stay

\begin{tabular}{|c|c|c|c|c|}
\hline & $\begin{array}{l}\text { Group I } \\
(n=24)\end{array}$ & $\begin{array}{c}\text { Group II } \\
(n=23)\end{array}$ & $\mathrm{t}$ value & $P$ value \\
\hline & Mean \pm SD & Mean \pm SD & & \\
\hline Age at which transfusion & $11.4 \pm 2.8$ & $12.2 \pm 1.8$ & 1.213 & 0.230 \\
\hline No. of transfusion & $2.1 \pm 0.6$ & $1.9 \pm 0.6$ & 1.450 & 0.152 \\
\hline
\end{tabular}

Requirements of blood transfusions : No blood transfusions were required in group I during the $1^{\text {st }}$ and $2^{\text {nd }}$ follow up. However in group II, $3(13 \%)$ infants in the $1^{\text {st }}$ follow up and $2(8.7 \%)$ infants in the $2^{\text {nd }}$ follow up required blood transfusions (Table -VI, VII).

Table VI : Blood transfusion (BT) status during $1^{\text {st }}$ Follow up

\begin{tabular}{|l|c|c|c|c|c|c|}
\hline \multirow{2}{*}{ At 6 weeks } & \multicolumn{2}{|c|}{$\begin{array}{c}\text { Group I } \\
(\mathrm{n}=24)\end{array}$} & \multicolumn{2}{c|}{$\begin{array}{c}\text { Group II } \\
(\mathrm{n}=23)\end{array}$} & $\begin{array}{c}\text { Chi } \\
\text { value }\end{array}$ & P value \\
\cline { 2 - 8 } & $\mathrm{n}$ & $\%$ & $\mathrm{n}$ & $\%$ & & \\
\hline No. of neonate required BT & 0 & 0.0 & 3 & 13.0 & & \\
No. of. neonate with out BT & 24 & 100 & 20 & 87.0 & 10.35 & 0.006 \\
\hline
\end{tabular}

Table VII : Blood transfusion (BT) status during 2nd Follow up

\begin{tabular}{|l|c|c|c|c|c|c|}
\hline \multirow{2}{*}{ At 10 weeks } & \multicolumn{2}{|c|}{$\begin{array}{c}\text { Group I } \\
(\mathrm{n}=24)\end{array}$} & \multicolumn{2}{c|}{$\begin{array}{c}\text { Group II } \\
(\mathrm{n}=23)\end{array}$} & $\begin{array}{c}\text { Chi } \\
\text { value }\end{array}$ & P value \\
\cline { 2 - 8 } & $\mathrm{n}$ & $\%$ & $\mathrm{n}$ & $\%$ & & \\
\hline No. of neonate required BT & 0 & 0.0 & 2 & 8.7 & & \\
No. of neonate without BT & 24 & 100 & 21 & 91.3 & 11.62 & 0.003 \\
\hline
\end{tabular}

\section{Discussion}

During last two decades many studies showed that the severity of anemia of prematurity and the need for red cell transfusion can be reduced by a combination therapy of rHuEPO, iron and folic acid and by limiting iatrogenic blood loss. ${ }^{15-19}$ Recombinant human erythropoietin (rHuEPO) is capable of increasing erythropoiesis with very little adverse effects in preterm infants. ${ }^{1}$ There is also no evidence of erythropoietin insensitivity therefore rHuEPO helps in reducing the number of red cell transfusion requirements in preterm infants. ${ }^{15-17,19}$

This is the first documented study has been conducted in Bangladesh to evaluate whether rHuEPO therapy reduces the need of transfusions in AOP in PTVLBW neonates.

Total 60 preterm very low birth weight neonates were enrolled in the study. Group I included 30 patients (rHuEPO, iron and folic acid were given) and Group II included 30 patients (iron and folic acid were given). There were a total of 13 infants who were dropped out from this study and they were excluded from the analysis.

Baseline haemoglobin levels were within the normal limit but gradually these levels were reduced in both groups. Reduction of hemoglobin level was more visible in Group II than in Group I, which was statistically significant $(P<0.001)$. This results were consistent with the other studies ${ }^{18}$.

Fall of haemoglobin $(\mathrm{Hb})$ level after birth is a physiological process for all neonate and it is exaggerated in preterm babies leading to various morbidities. One of the reasons for decrease $\mathrm{Hb}$ level is low concentration of erythropoietin (EPO). With this background studies are being conducted throughout the world in the use of erythropoietin in neonate to prevent anemia of prematurity. Ohls RK et al found that reticulocyte count and haemoglobin concentration was significantly higher in the rHuEPO treated group and the high level of hemoglobin concentration wasmaintained throughout the rHuEPO treatment period, this level was observed in all pre term infants and they maintained their $\mathrm{Hb}$ level same as the levels of term infants. ${ }^{20} \mathrm{AG}$ Bechensteen et al also reported that corrected reticulocyte count increased $(P<0.001)$ and Hematocrit increased $(P<0.05)$ in rHuEPO recipient group. ${ }^{17}$ These findings were consistent with our study.

Number of neonates who required blood transfusions in the first 3 weeks of their life was almost similar in both the groups. No patient required blood transfusions in group I during the $1^{\text {st }}$ and $2^{\text {nd }}$ follow up. By this way hazards of blood transfusions could be avoided in group I. In group II, however, $3(13 \%)$ infants in the $1^{\text {st }}$ follow up and $2(8.7 \%)$ infants in the $2^{\text {nd }}$ follow up required blood transfusions.

Prevention of anaemia in early neonatal (2weeks) period is not effective with rHuEPO therapy was found in our study and also in other studies. Maier $\mathrm{R}$ et al found VLBW infants showed no benefit in the reduction of blood transfusion in first 2 weeks after birth. ${ }^{13}$ Donato et al studied infants of birth weight $<1250 \mathrm{gm}$ found that the number of transfusions remained unchanged in infants who has received rHuEPO treatment before 2 weeks of age. ${ }^{21}$ The first evidence of a response to the three times weekly administration of rHuEPO is an increase in the reticulocyte count within 10 days, followed by increase red cell count, hemoglobin and hematocrit level, usually within 2 to 6 weeks ${ }^{22,23}$ Because of the length of time required for erythropoiesis, changes in haematocrit levels is usually not observed in less than 2 weeks of time and may require up to 6 weeks in some patients. In contrast with these results to similar studies conducted by Ohls $\mathrm{R}$ et al noted a significant decrease in number of blood transfusion in $1^{\text {st }}$ two weeks. ${ }^{24}$

Meyer and colleagues compared transfusion requirements within the 80 preterm infants ( $<32$ weeks gestation and $<1500 \mathrm{~g}$ ) receiving SC human recombinant erythropoietin at a dose of 200 units $/ \mathrm{kg}$ given three times weekly or placebo for 6 weeks. Iron supplementation consisted of 2 to $3 \mathrm{mg} / \mathrm{kg} /$ day oral iron. This was increased to 6 $\mathrm{mg} / \mathrm{kg} /$ day if feritin concentrations were $<65 \mu \mathrm{g} / \mathrm{dl}$. Erythropoietin recipients required fewer transfusions ( 0.17 versus 0.52 transfusions per infant, $p=0.002) .{ }^{25}$ In our study dose of EPO is similar and the duration is shorter than this study but we found the same effect. But Shannon K.M. et al found there was no significant difference in the number of transfusions required between the rHuEPO and the placebo groups in a double blinded study. ${ }^{14}$

In this study iron and folic acid was provided to the infants from day 14 of their life or as soon as enteral feeding was initiated. Infants were predominantly breast fed during the study period. Compliance with iron and folic acid supplementation was good in both groups during the follow up. In this study hematological values were higher and found statistically significant in group I compared to group II which indicates iron supplementation was needed along with EPO. In other studies, AG Bechensteen et al and Rolf F. Maier et al 2002 showed similar results from iron supplementation. ${ }^{17,18}$ 


\section{Conclusion}

Though the sample size is small but it is evident from this study that the combination of rHuEPO and Iron, folic acid therapy significantly reduces the number of blood transfusion as well as the percentage of infants who received any transfusion in AOP. Finally most important issue is that rHuEPO therapy also reduces the exposure of PTVLBW infants to various risks of multiple blood transfusions.

\section{References}

1. Rhondeau SM, Christensen RD, Ross MP, Rothstein G, Simmons MA. Responsiveness to recombinant human erythropoietin of marrow erythroid progenitors from infants With the "anemia of prematurity". J Pediatr. 1988 Jun; 112 (6) :935-40. | CrossRef |PubMed |

2. Blanchette V, Zipursky A. Neonatal Hematology. In: Neonatology: Pathophysiology and Manegement of the newborn. Philadelphia: Lippincott, 1987:638-686.

3. Kurtz A, Zapf J, Eckardt KU, Clemons G, Froesch ER, Bauer C. Insulin-like growth factor I in hypophysectomized rats Stimulates erythropoiesis. ProcNatlAcadSci U.S. A. 1988 Oct, 85 (20) :7825-9. | CrossRef | PubMed | PMC |

4. Perinatal education programme. Neonatal care manual 1999- 2002.

5. Roberts IAG, Murray AN. Hematology. In: Roberts IAG, editor. Roberton's Textbook of Neonatology. 4th ed. Philadelphia, USA: Elsevier limited, 2005: 739-72.

6. Patter FC, Southgate MW. Anaemia of prematurity. Pediatrics 2006.

7. Hunter N, Foster J, Chong A, McCutcheon S, Parnham D, Eaton S, et al. Transmission of prion diseases by blood transfusion. J Gen Virol. 2002 Nov, 83 (Pt 11) :2897-905. |PubMed|

8. Dodd RY. Emerging infections, transfusion safety, and epidemiology. N Engl J Med 2003 Sep 25; 349 (13) :1205-6. Epub 2003 Sep 18. | CrossRef | PubMed |

9. Pealer LN, AA Marfin, LR Petersen, RS Lanciotti, Page PL, Stramer SL, et al. Transmission of West Nile virus through blood transfusion in the United States in 2002. N Engl J Med 2003 Sep 25; 349 (13) :1236-45. Epub 2003 Sep 18. | CrossRef | PubMed |

10. Sazama K. Bacteria in blood for transfusion. A review. Arch Pathol Lab Med 1994 Apr; 118 (4) :350-65. | PubMed |

11. Division of Health Systems and Health Services, Program on Essential Drugs and Technology, Laboratory Services Public Health and Blood. Transfusion Medicine in Latin America. From 1994 to 2000. Washington, DC: PAHO, 2001.

12. De Halleux V, Truttmann A, Gagnon C, Bard $H$. The effect of blood transfusion on the hemoglobin oxygen dissociation curve of very early preterm infants During the first week of life. SeminPerinatol. 2002 Dec, 26 (6) :411-5. | CrossRef | PubMed |
13. Maier RF, Obladen $M$, Scigalla $P$, et al. The effect of epoetin beta (recombinant human erythropoietin) on the need for transfusion in very low birth weight infants. N Engl J Med 1994; 330: 1173-8

14. Shannon KM, Keith JF, Mentzer WC. Recombinant human erythropoietin stimulates erythropoiesis and reduces erythrocyte transfusions in very low birth weight preterm infants. Pediatrics 1995; 95: 1-8

15. Garcia MG, Hutson AD, Christensen RD. Effect of recombinant erythropoietin on late transfusions in the neonatal intensive care unit: a meta analysis. Journal of Perinatology 2002; 22: 108-11.

16. Ohls RK. The use of erythropoietin in neonates. Clinics in Perinatology 2000; 27:681-96.

17. Bechensteen AG, Haga $P$, Halvorsen $S$. Erythropoietin, protein and iron supplementation and the prevention of the anaemia of prematurity. Archives of Disease in Childhood 1993; 69: 645-53.

18. Maier RF, Obladen M, Mullrer HI. Early treatment with erythropoietin beta ameliorates anaemia and reduces transfusion requirements in infants with birth weights below 1000 g. Journal of pediatrics2002; 141: 8-15.

19. Meyer MP, Sharma E, Carsons M. Recombinant erythropoietin and blood transfusion in selected preterm infants. Archives of Disease in Childhood. Fetal and Neonatal Edition 2003; 88: 41-45.

20. Ohls RK, Christensen RD. Recombinant erythropoietin compared with erythrocyte transfusion in the treatment of anaemia of prematurity. J Pediatr 1991;119:781-88.

21. Donato 11 ,Vain N, Rendo P et al, Effect of Early versus Late Recombinant Human Erythropoietin on Transfusion Requirements in Premature Infants results of A Randomized, Placebo -controlled, Multicenter Trial. PEDIATRICS 2000; 105(5): 1066-72.

22. Eschbach JW, Egrie JC, Downing MR Correction of the Anaemia of End Stage Renal Disease with Recombinant Human Erythropoietin. NEJM .1987; 316: 73-8

23. Eschbach JW, Abdul Hadi MH, Browne JK Recombinant Human Erythropoietin in anaemic patient with End Stage Renal Disease. Ann Intern Med 1989, 111: 992-1000

24. Ohls RK, Osborne KA, Christensen RD. Efficacy and cost analysis of treating very low birth weight infants with erythropoietin during their first two weeks of life: a randomized, placebo controlled trial. J Pediatr 1995; 126: 421-6

25. Meyer MP, Meyer JH, Commerford A. Recombinant human erythropoietin in the treatment of theanaemia of prematurity: results of a double-blind, placebo-controlled study. Pediatrics 1994; 93 (9): 18-23 